\title{
Treatment of purulo-necrotic pathology complicated by associated bacterial microflora in the hoof area in cows
}

D.V. Dashko*

FSBEI HE Irkutsk State Agrarian University n.a. A.A. Yezhevsky, Irkutsk, Russia

\begin{abstract}
The article is devoted to the problem of purulo-necrotic lesions of the distal extremities, including necrobacteriosis, the study of the role of concomitant bacterial microflora in the occurrence of the disease, as well as the development of new, more effective products safe for animals and product quality. The therapeutic efficacy of the drug Ceftiofur-VS was studied as a result of its use in purulo-necrotic pathologies in the hoof area in cattle. Studies on the comparative therapeutic effectiveness of the drug Ceftiofur-VS in necrobacteriosis in cattle, complicated by associations of microorganisms, were conducted in 2019-2020 in the farms of the Irkutsk region. The objects of the study were 74 cows with purulo-necrotic hoof lesions, with a laboratory-confirmed diagnosis of necrobacteriosis, which were divided into two groups: experimental (50 heads) and control (24 heads). It was found that when using the drug Ceftiofur-VS, a positive therapeutic effect occurred in 46 cows and amounted to $92 \%$. In the animals of the experimental group, signs of healing were noted already on the 4th day after the start of treatment: the inflammatory reaction (edema and hyperemia) and the affected area significantly decreased, fully cleared from the purulo-necrotic substrate. On the 5th day, young granulations appeared, on the 7th-8th day, signs of purulent inflammation were significantly leveled, exudation from wounds stopped, and marginal epidermization was noted. The average area of the wound was on average about $40 \%$ of the original one. The recovery time of animals with necrobacteriosis complicated by associations of microorganisms was, on average, 11-12 days.
\end{abstract}

\section{Introduction}

In modern production conditions, there are some features of dairy livestock complexes, namely: narrow specialization of production, use of highly productive animals and increased concentration of livestock in limited areas. Under these production conditions, even a slight deviation from the zootechnical, veterinary and sanitary standards for keeping and feeding animals provokes a significant increase in the concentration of opportunistic microflora in the air and in the premises. These factors reduce the natural resistance of the animal body, suppress the immune system, as a result of which the pathogenic bacterial

* Corresponding author: den120577@bk.ru 
microflora spreads quickly [1-4]. Most researchers tend to believe that the results of pathogenic and conditionally pathogenic microflora activation in cows give rise to the development of three interrelated areas: the pelvic limbs, the breast and the reproductive organs. These above-mentioned pathologies are etiologically caused by the association of microorganisms and cause significant economic losses to farms due to reduced milk productivity, impaired reproductive function, premature culling of cows, and cost for sick animals treatment $[12,13]$.

A special place among these pathologies is occupied by purulo-necrotic diseases of the distal extremities, including necrobacteriosis (Necrobacteriosis) [6]. It was noted that in different categories of farms, the pathological processes of the distal extremities of cows are caused or complicated by the association of microorganisms of the families: Staphylococcus spp., Streptococcus spp., Enterococcus spp., Escherichia coli, Proteus spp., Pseudomonas spp., Klebsiella spp., Clostridium spp., Spiro chaeta spp., Fusobacterium spp., Bacteroides spp. et al. [1-4, 14, 15]. The appearance of highly virulent strains among representatives of conditionally pathogenic microflora, which are characterized by resistance to most known antimicrobial agents, determines the spread of these pathologies and significantly reduces the effectiveness of therapeutic treatments for necrobacteriosis and associated bacterial diseases of the extremities [15].

All of the above indicates the relevance of research on the role of microflora in the occurrence of associated bacterioses and the development of new, more effective means and methods in veterinary practice, safe for animals and product quality [5, 7-10].

The purpose of our research was to study the therapeutic effectiveness of the drug Ceftiofur-VS (active substance ceftiofur hydrochloride $50 \mathrm{mg}$ ), developed and manufactured by Vetsintez LLC, in case of necrobacteriosis in cows complicated by associations of microorganisms.

\section{Materials and methods}

The research was conducted in 2019-2020 in the farms of the Irkutsk region. The objects of the study were 74 cows with purulo-necrotic lesions of the hooves. To confirm the diagnosis of necrobacteriosis, samples were taken from animals and sent to the laboratory, according to the generally accepted method in veterinary diagnostics [11]. As the sick animals were isolated, two groups were formed from them: the first (experimental) group in the amount of 50 heads and the second (control) - 24 heads. For the treatment of necrobacteriosis forms of the extremities complicated by bacterial infection in animals of the experimental group, the drug Ceftiofur-VS was used, which was administered intramuscularly at a dose of $1 \mathrm{ml} / 50 \mathrm{~kg}$ of body weight daily, during five days. For control group animals treatment, the comparison drug Trimetosul $48 \%$ (content of active substances in $1 \mathrm{ml}$ : sodium sulfadiazine $400 \mathrm{mg}$ and trimethoprim $80 \mathrm{mg}$ ) was used, which was administered intramuscularly at a dose of $1 \mathrm{ml} / 30 \mathrm{~kg}$ of body weight daily, during five days.

In addition, 10 heads of healthy cows were selected, from which blood was taken for research. In order to assess the therapeutic effectiveness of both drugs, each sick animal was monitored daily from the beginning of treatment, which lasted 30 days. In each of the groups, blood samples were taken from the first 10 animals before therapy course and 5 days after its end to measure hematological parameters. From the total number of livestock of each group, the number of recovered animals and the time of recovery were taken into account.

For mathematical analysis of the obtained data, the software package "Statistica" was used. 


\section{Results and discussion}

It was found that when using the drug Ceftiofur-VS, a positive therapeutic effect occurred in 46 cows and amounted to $92 \%$. When treated with Trimetosul $48 \%$, the therapeutic effect was registered in 21 cows, which was $87.5 \%$. At the same time, in the animals of the experimental groups, signs of regenerative processes were noted starting from the 4th day after the start of treatment. The inflammatory reaction (swelling, hyperemia) and the area of the lesion significantly decreased in size, and the purulo-necrotic substrate was cleared. On the 5th day, granulation tissue began to appear in places. Starting from 7-8 days, the signs of septic inflammation were significantly leveled, exudative phenomena faded, and marginal epidermization appeared. On average, the wound area was $40 \%$ of the area of the original wound defect. Complete healing occurred in the period from $11.8 \pm 1.6$ to $13.6 \pm 1.4$ days. In the second (control) group, the healing process was noted on the 6th day. On the 8th day, in some animals, granulation tissue appeared. On days 10-11, marginal epithelialization appeared, the average wound area was $50 \%$ of the original one. Complete healing occurred in the period from $15.1 \pm 1.1$ to $17.6 \pm 1.6$ days.

When studying the dynamics of changes in the hematological parameters of the sick animals blood during the treatment period, significant deviations in the blood parameters of cows of the experimental and control groups were not detected (Table 1).

Table 1. Morphological parameters of cow blood in associated limb bacteriosis $(\mathrm{n}=10, \mathrm{M} \pm \mathrm{m})$

\begin{tabular}{|c|c|c|c|c|c|c|}
\hline \multirow[b]{2}{*}{ Indicators } & \multirow{2}{*}{$\begin{array}{l}\text { Healthy } \\
\text { animals }\end{array}$} & \multicolumn{2}{|c|}{1 experimental group } & \multicolumn{2}{|c|}{2 control group } & \multirow[b]{2}{*}{ Norm } \\
\hline & & $\begin{array}{l}\text { before } \\
\text { treatment }\end{array}$ & $\begin{array}{c}\text { after } \\
\text { treatment }\end{array}$ & $\begin{array}{c}\text { before } \\
\text { treatment }\end{array}$ & $\begin{array}{c}\text { after } \\
\text { treatment }\end{array}$ & \\
\hline hemoglobin, g/l & $104.7 \pm 1.27$ & $96.4 . \pm 0.54$ & $\begin{array}{c}103.8 \pm 0.22 \\
*\end{array}$ & $94.2 \pm 0.82$ & $96.8 \pm 0.22$ & $95-125$ \\
\hline $\begin{array}{l}\text { red blood cells, } \\
\qquad 10^{\wedge} 12 / 1\end{array}$ & $5.1 \pm 0.12$ & $4.9 \pm 0.76$ & $5.5 \pm 0.16$ & $4.9 \pm 0.36$ & $5.1 \pm 0.64$ & $5-7.5$ \\
\hline $\begin{array}{l}\text { white blood cells, } \\
\mathrm{g} / 1\end{array}$ & $7.0 \pm 0.25$ & $11.2 \pm 0.32$ & $7.1 \pm 0.64 *$ & $12.4 \pm 0.23$ & $9.7 \pm 0.32 *$ & $6-12$ \\
\hline basophils, $\%$ & - & - & - & - & - & $0-2$ \\
\hline eosinophils, $\%$ & $5.9 \pm 0.23$ & $6.1 \pm 0.43$ & $5.7 \pm 0.88$ & $6.2 \pm 0.10$ & $5.4 \pm 0.56^{*}$ & $5-8$ \\
\hline $\begin{array}{c}\text { neutrophils: stab, } \\
\%\end{array}$ & $2.2 \pm 0.20$ & $6.9 \pm 0.46$ & $2.6 \pm 0.22 * *$ & $5.6 \pm 0.24$ & $3.1 \pm 0.24 * *$ & $2-5$ \\
\hline segmented, \% & $30.4 \pm 0.95$ & $41.2 \pm 0.54$ & $32.1 \pm 0.32 *$ & $41.6 \pm 0.74$ & $39.2 \pm 0.61$ & $20-35$ \\
\hline lymphocytes, \% & $52.2 \pm 0.76$ & $40.2 \pm 0.32$ & $52.8 \pm 0.54 *$ & $41.6 \pm 1.03$ & $49.3 \pm 0.94 *$ & $40-65$ \\
\hline monocytes, $\%$ & $3.1 \pm 0.94$ & $9.0 \pm 0.24$ & $4.2 \pm 0.86^{*}$ & $7.2 \pm 1.36$ & $5.4 \pm 1.40^{*}$ & $2-7$ \\
\hline
\end{tabular}

Note: ${ }^{*} \mathrm{p}<0.05 ; * * \mathrm{p}<0.01$.

Before the start of treatment, the number of stab white blood cells in the blood of animals of both groups was higher than in healthy animals, but was within the physiological norm. At the end of the experiment, these indicators significantly decreased to similar indicators in healthy animals.

In biochemical studies of the experimental animals blood, the following quantitative and qualitative changes were noted (Table 2). 
Table 2. Biochemical parameters of the blood of cows with associated bacteriosis of the extremities $(n=10, M \pm m)$

\begin{tabular}{|c|c|c|c|c|c|c|}
\hline \multirow[b]{2}{*}{ Indicators } & \multirow[b]{2}{*}{$\begin{array}{l}\text { Healthy } \\
\text { animals }\end{array}$} & \multicolumn{2}{|c|}{1 experimental group } & \multicolumn{2}{|c|}{2 control group } & \multirow[b]{2}{*}{ Norm } \\
\hline & & $\begin{array}{l}\text { before } \\
\text { treatment }\end{array}$ & $\begin{array}{c}\text { after } \\
\text { treatment }\end{array}$ & $\begin{array}{l}\text { before } \\
\text { treatment }\end{array}$ & $\begin{array}{c}\text { after } \\
\text { treatment }\end{array}$ & \\
\hline total protein, $g / 1$ & $84.6 \pm 2.34$ & $74.8 \pm 1.96$ & $80.1 \pm 2.53$ & $74.2 \pm 2.61$ & $76.2 \pm 1.34$ & $72-86$ \\
\hline albumins, $\%$ & $46.2 \pm 1.23$ & $44.2 \pm 1.63$ & $44.5 \pm 1.26$ & $45.1 \pm 3.19$ & $46.4 \pm 1.06$ & $38-50$ \\
\hline$\alpha$-globulins, $\%$ & $14.2 \pm 0.70$ & $15.4 \pm 1.04$ & $14.9 \pm 0.24$ & $14.1 \pm 0.52$ & $15.6 \pm 0.64$ & $12-20$ \\
\hline$\beta$-globulins, $\%$ & $13.1 \pm 0.22$ & $12.6 \pm 0.56$ & $14.6 \pm 0.61$ & $12.2 \pm 0.23$ & $11.8 \pm 0.51$ & $10-16$ \\
\hline y-globulins, $\%$ & $25.5 \pm 0.34$ & $27.8 \pm 0.98$ & $26.0 \pm 0.91$ & $28.6 \pm 0.64$ & $26.8 \pm 0.76$ & $25-35$ \\
\hline
\end{tabular}

The indicators of protein and protein fractions content in the blood of sick animals were within the physiological norm and did not significantly change during the entire study period.

The species composition of the microflora from the lesions had the following picture (Table 3). The microbial landscape of the lesions was characterized mainly by six bacterial species: S. aureus, S. epidermidis, S. faecalis, E. coli, P. vulgaris, and F. necrophorum.

Table 3. Species composition of microflora from purulo-necrotic foci $(\mathrm{n}=10, \mathrm{M} \pm \mathrm{m})$

\begin{tabular}{|c|c|c|c|c|}
\hline \multirow{2}{*}{$\begin{array}{l}\text { Type of } \\
\text { bacteria }\end{array}$} & \multicolumn{2}{|c|}{1 experimental group } & \multicolumn{2}{|c|}{2 control group } \\
\hline & $\begin{array}{c}\text { before } \\
\text { treatment }\end{array}$ & $\begin{array}{c}\text { after } \\
\text { treatment }\end{array}$ & $\begin{array}{l}\text { before } \\
\text { treatment }\end{array}$ & $\begin{array}{c}\text { after } \\
\text { treatment }\end{array}$ \\
\hline S.aureus & $39.5 \pm 2.3$ & - & $38.4 \pm 3.2$ & $3.96 \pm 0.74$ \\
\hline S. epidermidis & $42.7 \pm 2.7$ & - & $51.1 \pm 2.8$ & - \\
\hline S. faecalis & $21.1 \pm 3.2$ & $0.34 \pm 0.02$ & $22.3 \pm 1.8$ & - \\
\hline E. coli & $54.1 \pm 2.6$ & - & $44.1 \pm 4.2$ & $5.06 \pm 0.34$ \\
\hline P. vulgaris & $49.5 \pm 3.6$ & - & $51.1 \pm 3.1$ & $4.18 \pm 0.56$ \\
\hline $\begin{array}{c}\text { F. } \\
\text { necrophorum }\end{array}$ & $\begin{array}{l}\text { presence } \\
\text { of growth }\end{array}$ & $\begin{array}{l}\text { absense of } \\
\text { growth }\end{array}$ & $\begin{array}{l}\text { presence } \\
\text { of growth }\end{array}$ & $\begin{array}{l}\text { absense of } \\
\text { growth }\end{array}$ \\
\hline
\end{tabular}

After the course of animals treatment with Ceftiofur-VS, there was no growth of $S$. aureus, E. coli, P. vulgaris, F. necrophorum in the samples taken from the lesions. In the samples taken in the second group of animals treated with Trimetosul $48 \%, P$. vulgaris, $S$. aureus and E. coli were isolated, but their number decreased by $88.8 \%$.

The cost-effectiveness of one animal course treatment with the drug Ceftiofur-VS is 892 rubles lower than the course therapy with the comparison drug Trimethosul $48 \%$.

\section{Conclusion}

Thus, the drug Ceftiofur-VS is a highly effective treatment for cows with an associated form of necrobacteriosis, with a therapeutic effectiveness of $92 \%$. The recovery time of animals with necrobacteriosis complicated by associations of microorganisms was, on average, 11-12 days. This was confirmed by the results of clinical examination of animals, laboratory blood tests and bacteriological studies of pathological exudate.

It should be noted that the dosage forms based on ceftiofur hydrochloride are the only ones among all antibiotics that are not excreted in milk when used in lactating cows. 


\section{References}

1. A.M. Ablov, E.V. Anganova, A.S. Batomunkuyev, Vestnik of the OmSAU, 3 (15), 2227 (2014)

2. A.M. Ablov, E.V. Anganova, A.S. Batomunkuyev, Vestnik of the IrSAA, 65, 65-71 (2014).

3. A.S. Batomunkuyev, A.M. Ablov, Clostridioses of agricultural animals on the territory of the Irkutsk region, In the collection: Problems of species and age morphology. Materials of the All-Russian Scientific and Practical Conference with international participation dedicated to the 100th anniversary of Professor Kirill Antonovich Vasiliev. - Ulan-Ude: Publishing House of the Buryat SAA, 178-186 (2019)

4. A.S. Batomunkuyev, A.M. Ablov, I.G. Trofimov, D.V. Dashko, Ya.V. Lapa, Vestnik of Buryat state Academy of Agriculture named after V. Philippov, 47 (2018)

5. D.V. Dashko, V.N. Tarasevich, Materials of the VIII International Scientific and Practical Conference "Climate, ecology, agriculture of Eurasia", v. Molodezhny: Publishing house of the Irkutsk SAU, 137-143 (2019)

6. D.V. Dashko, I.I. Silkin, Veterinary surgical terminology (v. Molodezhny, Publishing house of the Irkutsk SAU, 101, 2020)

7. D.V. Dashko, I.I. Silkin, V.N. Tarasevich, Transcranial electroanalgesia and electrical stimulation in veterinary medicine (v. Molodezhny: Publishing house of the Irkutsk SAU, 144, 2020)

8. D.V. Dashko, Transcranial electroanalgesia and electrical stimulation in veterinary medicine, 56 International Scientific Conference of the Eurasian Scientific Association, 56 (3), 267-269 (2019)

9. D.V. Dashko, Experimental and clinical justification of the method of electrical analgesia in dogs (Omsk: Publishing house of the IVM OmSAU, 168, 2003)

10. E.N. Zontakh, L.Ya. Yushkova, I.V. Meltsov, Application and testing of the medical preparation vinilin (Shostakovsky's balm) in veterinary medicine, In the collection: Agrarian science - agricultural production of Mongolia, Siberia and Kazakhstan. Collection of scientific reports of the XIII International Scientific and Practical Conference, Novosibirsk: Publishing House of the IIC GNU SibNSHB, 2025 (2010)

11. I.P. Kondrakhin, N.V. Kurilov, A.G. Malakhov, Clinical laboratory diagnostics in veterinary medicine (M.: Agropromizdat, 287, 1985)

12. L.Ya. Yushkova, I.V. Meltsov, B.N. Balyberdin Issues of regulatory and legal regulation in veterinary medicine, 2, 369-371 (2015)

13. J. Mitev, T.Penev, N.Vasilev, Trakia Journal of Sciences, 10 (I), 85-91 (2012)

14. J.A. Hernandez, E.J. Garbarino, J.K. Shearer, JAVMA, 230 (1), 89-93 (2007)

15. T.A. McAllister, L.J. Yanke, G.D. Inglis, Advances in Dairy Technology, 13, 229-247 (2001) 